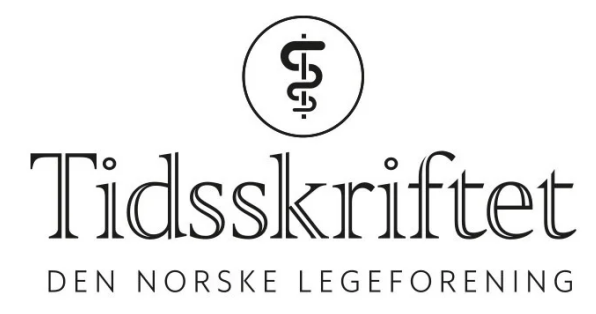

\title{
Manuskriptet må være tydelig skrevet, helst maskinskrevet
}

TIDLIGERE I TIDSSKRIFTET

\section{JULIE DIDRIKSEN}

julie.didriksen@tidsskriftet.no

Tidsskriftet

Før internett viste seg å ikke være en døgnflue, ble artikler sendt inn på papir, noen av dem håndskrevet. I denne saken fra utgave 19 i 1929 beskriver redaksjonen hvordan artiklene best sendes inn - de skulle helst være maskinskrevet, håndskrift ble kun godtatt hvis det var tydelig skrevet med blekk. Hvis ikke ble det dyrt hos trykkeriet (Tidsskr Nor Lægeforen 1929; 49: 964). Du finner mer oppdaterte råd i vår forfatterveiledning på tidsskriftet.no.

Om innsendte artiklers optagelse i «Tidsskriftet».

Til våre ærede innsendere og medarbeidere! 


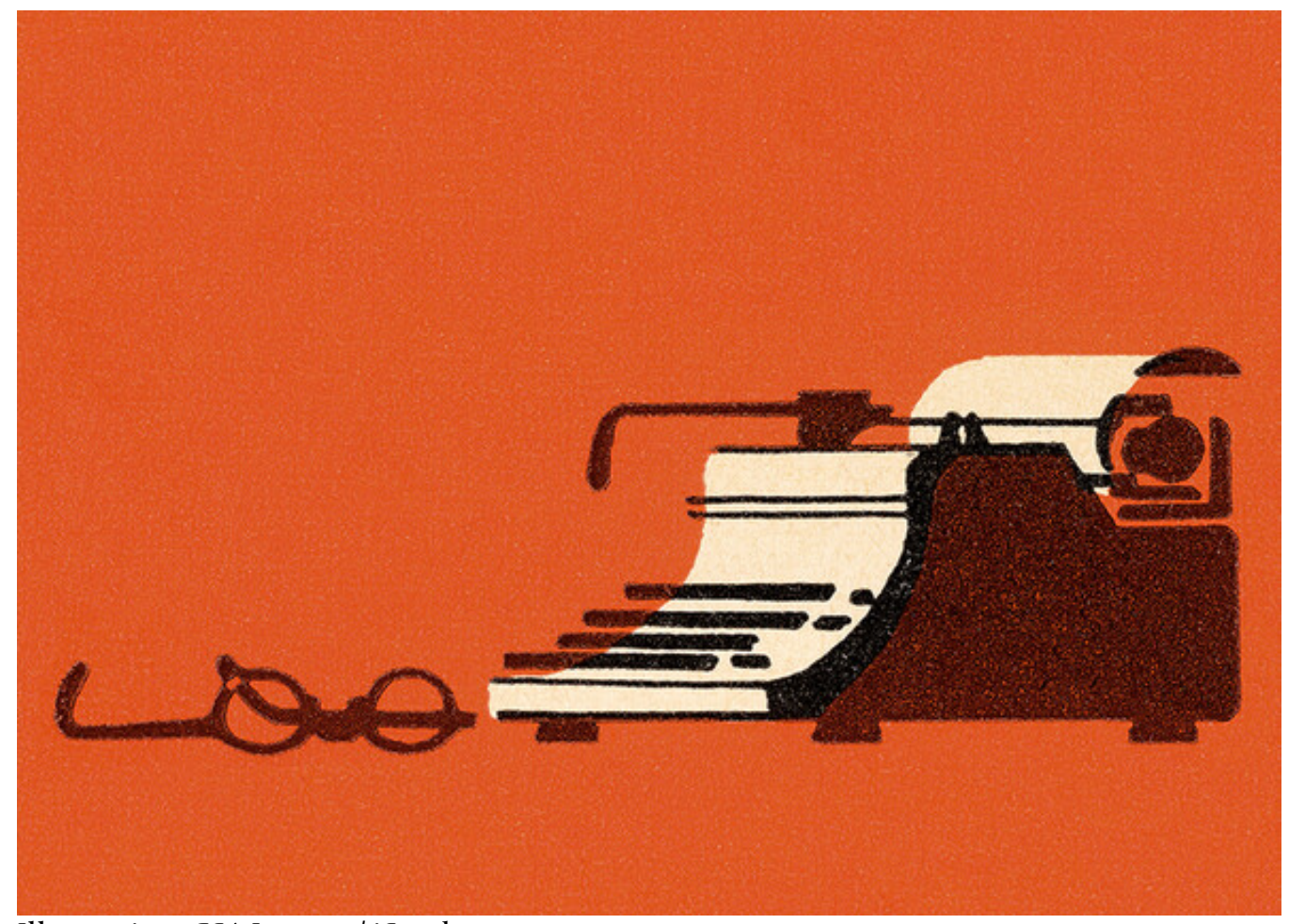

Illustrasjon: CSA Images / iStock

Da der ofte mottas manuskripter, som er utydelig, til dels meget utydelig skrevet, - da mange er skrevet med blokklapper eller med blyant etc., ønsker vi gjerne å innprente nedenstående regler:

1. Alt manuskript må være tydelig skrevet, helst maskinskrevet. Er det utydelig skrevet, returneres vedkommende artikkel. Setteren forlanger tillegg for utydelig manuskript. Trykningsomkostningene er dyre nok i forveien, om de ikke skal fordyres ved utydelig skrift i manuskriptet. Rettelser i dette må være tydelig skrevet.

2. Skriv alltid med blekk, hvis manuskriptet ikke er maskinskrevet. Blyantskrevet manuskript er vanskeligere å sette og koster dessuten mere i opsetning efter trykkeritariffen. Blyantskrevet manuskript mottas derfor ikke. Derved kan opsetningen skje hurtigere, idet manuskriptet i tilfelle kan fordeles på flere settere. Skriv ikke på papir av mindre format enn kvart («skriveboksformat»). Manuskript på almindelig blokkpapir blir sendt tilbake til omskrivning. Slike blokklapper kan lett bli borte.

"Enkelte innsendere skriver medisinske termini og navn så slurvet, at selv den dyktigste og i opsetning av lagevidenskapelige artikler mest øvede setter meget ofte må begå feil»

3. Alle person- og andre egennavn, likeså uttrykk fra fremmede sprog, ikke minst medisinske termini, må især skrives tydelig. Setterne forstår som regel ikke fremmede sprog og har derfor vanskelig for å sette riktig, når ikke manuskriptet er tydelig. Enkelte innsendere skriver medisinske termini og navn så slurvet, at selv den dyktigste og i opsetning av lægevidenskapelige artikler mest øvede setter meget ofte må begå feil.

4. Ved korrekturlesningen bør der foretas minst mulig forandringer i selve teksten, da ellers trykningen både fordyres og forsinkes. Forandringer i den i «Tidsskriftet» brukte ortografi må ikke foretas. Korrektur bedes tilbakesendt straks.

5. Mulige rettelser i manuskriptet må være så tydelige, at der ingen tvil er om meningen.

Publisert: 26. juli 2021. Tidsskr Nor Legeforen. DOI: 10.4045/tidsskr.21.0286

(C) Tidsskrift for Den norske legeforening 2023. Lastet ned fra tidsskriftet.no 26. april 2023. 